Innlegg på inntil $\mathbf{4 0 0}$ ord lastes opp i http://mc.manuscriptcentral.com/tidsskriftet.

Redaksjonen forbeholder seg retten til å foreta redaksjonelle endringer.

Forfattere av vitenskapelige artikler har tilsvarsrett (jf. Vancouver-gruppens regler).

\section{Erfaringsbaserte materialer og selvstendige leger}

I Tidsskriftet nr. 15/2011 rapporterte vi våre erfaringer med en ny behandling $\mathrm{av}$ barn med hjertefeil (1). Viktige prinsipielle spørsmål er påpekt $\mathrm{i}$ to ledsagende lederartikler $(2,3)$.

Burde vi ha gjennomført en randomisert studie? Vi vil advare mot at det beste blir det godes fiende: Det finnes også andre veier til kunnskap. Ikke-kontrollerte pasientserier, kasuistikker og registerdata beskriver alle pasienter uten kontrollgruppe. Mener man virkelig at slike materialer er verdiløse? Også når de sammenfaller med eksperimentelle data, klinisk erfaring og sunn fornuft? I 2007, da vi startet opp vår virksomhet, fantes det mer enn 50 vitenskapelige publikasjoner om den aktuelle behandlingsformen, inkl. dyreforsøk, tekniske tester og kliniske pasientserier. En av oss (GD) hadde fått opplæring i metoden ved et verdensledende senter (Hospital for Sick Kids, Toronto, Canada). Likevel hevdes det at dette er utprøvende behandling (3): Så strenge krav til kunnskapsgrunnlaget underminerer store deler av etablert medisinsk praksis.

Mye medisinsk fagutvikling næres av samspillet mellom teknologiske nyvinninger og behandling av enkeltpasienter. Randomiserte intervensjonsstudier er mangelvare i pediatri. Mener man at det skal etableres et prospektivt forskningsprosjekt hver gang man gjør noe nytt? En utopisk tanke. Skal vi i stedet anse all annen fagutvikling som «uvitenskapelig»? Eller skal vi gjøre det beste ut av situasjonen: systematisere og publisere våre erfaringer i etterkant?

Var vår virksomhet etisk betenkelig ettersom regional etisk komité (REK) ikke hadde gitt forhåndsgodkjenning? (3). Dels hevdes det at metoden må karakteriseres som «utprøvende» og dermed fremleggelsespliktig. Men samtidig kritiseres vi for å ha anvendt en design uten vitenskapelig utsagnskraft. Altså: sett fra etisk komités ståsted er prosjektet vitenskap; sett fra akademia er det uvitenskapelig. Vi vil minne om at selv om vi ikke innhentet forhåndsgodkjenning, ble komiteen konsultert da vi gjorde opp materialet, og uttalte at prosjektet ikke var fremleggelsespliktig.

Det er en grunnleggende uenighet om hvilke etiske problemstillinger vårt prosjekt aktualiserer. Det henvises til forskrifter, stortingsmeldinger og kunnskapsoppsummeringer. Vi underkjenner ikke nødvendigheten av slikt rammeverk, men vil hevde at medisinsk etikk først og fremst handler om dyder - ikke regler. Imperativene om å gjøre godt og ikke skade oppstår i møtet med «hiin enkelte» - og i dette møtet er det legens holdninger, og ikke forvaltningens formalia, som har avgjørende betydning. Slik er den kliniske virkeligheten, og for etikkomiteen burde det være viktigere å bidra til holdningsutvikling fremfor regelstyring. Vi mener det ville være uetisk ikke å tilby denne pasientgruppen kateterbasert innsetting av pulmonalklaff.

Altfor mye er overlatt til leger som vil være først ute med ny behandling, hevdes det (3). Utsagnet avdekker en grunnleggende mistillit til den moralske standarden i egen yrkesgruppe, og peker på hva som bør gjøres: frata legene makt, øke kontrollen over deres virksomhet, og dermed bidra til ytterligere deprofesjonalisering. Mener man virkelig at dette er til gagn for pasientene? Vi er overbevist om det motsatte. Vi mener pasientene trenger selvstendige, ansvarlige, moralsk integrerte leger, ikke bare forskrifter og lover, påbud og rettigheter. Altfor mye er i dag overlatt til byråkrater og jurister.

\section{Vegard Bruun Wyller \\ Erik Thaulow \\ Lars Aaberge \\ Gaute Døhlen \\ Oslo Universitetssykehus, Rikshospitalet}

Vegard Bruun Wyller (f. 1972) er dr.med., spesialist i pediatri og arbeider som overlege og førsteamanuensis ved Kvinne- og barnklinikken.

Erik Thaulow (f. 1949) er leder for Barnehjerte-, lunge- og allergiseksjonen.

Lars Aaberge (f. 1954) er overlege dr.med. og avdelingsleder ved Kardiologisk avdeling.

Gaute Døhlen (f. 1965) er spesialist i barnesykdommer og overlege på Barnehjerteseksjonen.

\section{Litteratur}

1. Wyller VB, Aaberge L, Thaulow E et al. Perkutan innsetting av kunstig pulmonalklaff ved medfødt hjertefeil. Tidsskr Nor Legeforen 2011; 131: 1289-93.

2. Bretthauer $M$, Haug $C$. Hva er etablert behandling? Tidsskr Nor Legeforen 2011; 131: 1275.

3. Evensen SA. Etikkvurdering ved innføring av ny behandling. Tidsskr Nor Legeforen 2011; 131: 1276.

\section{Ja til kunnskapsbasert praksis}

I en kommentarartikkel i Tidsskriftet nr. 12/2011 konkluderer Torgeir Bruun Wyller at evidensbasert medisin er blitt vulgarisert til bare å handle om evidens, og systematisk nedvurderer erfaringsbasert kunnskap (1).

Den allment aksepterte definisjonen av evidensbasert medisin, heretter kalt «kunnskapsbasert praksis», er å ta faglige avgjørelser ved å integrere:

- systematisk innhentet forskningsbasert kunnskap

- erfaringsbasert kunnskap

- pasientens ønsker og behov i en gitt situasjon (se www.kunnskapsbasertpraksis.no).

I klinisk medisin er «det finslipte skjønnet», som Wyller refererer til, et uttrykk for erfaringsbasert kunnskap, og innen kunnskapsbasert praksis omtales dette også som «klinisk ekspertise». Klinisk ekspertise inkluderer klinisk skjønn, evne til god kommunikasjon, dybdekunnskap i biologi og fysiologi og kjennskap til risikofaktorer, komorbiditet og legemiddelbruk hos den enkelte pasient. Bruk av klinisk ekspertise er derfor avgjørende i møter mellom helsearbeidere og enkeltpasienter, og er et viktig element i kunnskapsbasert praksis. Videre kan den eksplisitte vektleggingen av pasientens ønsker og behov sikre god brukermedvirkning. I utvikling av kunnskapsbaserte retningslinjer (og i beslutninger av mer prinsipiell karakter) vil imidlertid en samlet erfaringsbasert kunnskap og ekspertise fra flere klinikere og eksperter bidra, kombinert med kvalitetsvurdert forskningsbasert kunnskap og en sammenstilling av pasientpreferanser (2).

Wyller presenterer en pyramide som er ukjent for oss. Pyramiden utgjør trolig en hybrid av to ulike modeller: evidenshierarkiet og kunnskapspyramiden. Evidenshierarkiet rangerer informasjonskilder basert på hvor pålitelig kunnskap kildene gir om effekter av ulike tiltak i helsetjenesten. I anvendelsen av forskningsbasert kunnskap i klinisk praksis må gode klinikere «filtrere forskningen gjennom sunt skjønn og erfaringsbasert kunnskap», slik Wyller treffende formulerer det. Kunnskapspyramiden (fig 1) er ikke en modell for rangering av forskningsbasert kunnskap alene, men skal hjelpe helsearbeidere til å forstå hvor de enklest kan finne gyldig og anvendelig kunnskap om diagnostikk, prognose og behandling (3). I denne pyramiden er ekspertvurderinger plassert øverst 